\title{
Peran Dinas Lingkungan Hidup Kabupaten Bone Dalam Mencegah Terjadinya Pencemaran Limbah Rumah Sakit Berdasarkan Undang-Undang Nomor 32 Tahun 2009 Tentang Perlindungan dan Pengelolaan Lingkungan Hidup
}

\author{
Masnawati \\ Institut Agama Islam Negeri (IAIN) Bone \\ mansnawatihtniainbone@gmail.com
}

\begin{abstract}
Abstrak
Tujuan dari penelitian ini adalah (1) untuk mengetahui apa faktor penghambat Dinas Lingkungan Hidup Kabupaten Bone dalam mencegah terjadinya pencemaran limbah rumah sakit; (2) untuk mengetahui apa upaya yang dilakukan Dinas Lingkungan Hidup Kabupaten Bone dalam mencegah terjadinya pencemaran limbah rumah sakit.Metode yang digunakan dalam penelitian ini adalah penelitian lapangan dengan pendekatan normatif empiris yang yang menggunakan sumber data primer dan sumber data sekunder yang terdiri dari bahan hukum primer, bahan hukum sekunder, dan bahan hukum tersier. Adapun teknik pengumpulan data yakni dengan cara melakukan wawancara dan melakukan studi dokumen kepustakaan yang erat kaitannya dengan objek yang diteliti, kemudian dianalisis dengan cara kualitatif dengan menggunakan teknik pengolahan data yakni reduksi data, penyajian data, dan penarikan kesimpulan.Hasil penelitian ini menunjukkan bahwa dalam Peran Dinas Lingkungan hidup Kabupaten Bone belum efektif karena masi ada rumah sakit yang mencemari masyarakat setempat. Adapun faktor penghambat Dinas Lingkungan Hidup Kabupaten Bone yaitu (a) instalasi pengolahan air limbah (IPAL) tidak berfungsi dengan baik, (b) kurangnya pengawasan dari Dnas Lingkungan Hidup Kabupaten Bone, (c) kapasitas limbahnya melebihi dari kapasitas pengolahanya, (d) kurangnya kompratif dari pihak rumah sakit.
\end{abstract}

\section{Kata Kunci: Peran Dinas Lingkungan Hidup, Mencegah Terjadinya Pencemaran Limbah Rumah Sakit dan Undang-Undang Nomor 32 Tahun 2009}




\section{PENDAHULUAN}

Lingkungan hidup sering disebut sebagai lingkungan, istilah yang dapat mencakup segala makhluk hidup di alam yang ada di bumi atau bagian dari bumi, yang berfungsi secara alami tampa campur tangan manusia yang berlebihan. Dalam lingkungan hidup terdapat ekosistem, yaitu tatanan unsur lingkungan hidup yang merupakan kesatuan utuh menyeluruh dan saling mempengruhi dalam membentuk keseimbangan, stabilitas, dan prduktivitas lingkungan hidup. ${ }^{159}$

Merujuk pada definisi di atas, maka lingkungan hidup Indoneia merupakan wawasan nusantara, yang menempati posisi silang antara dua benua dan dua samudra dengan iklim tropis dan cuaca serta musim yang memberikan kondisi alamiah dan kedudukan dengan pran strategis yang tinggi nilainya, tempat bangsa Indonesia menyelegrakan kehidupan bernegara dalam segala aspeknya. ${ }^{160}$

Indonesia dengan beragam bentuk fisik (relief) dan penduduknya memiliki beberapa permasalahan yang berhubungan dengan lingkungan hidup permasalahan lingkungan hidup Indonesia terjadi diberbagai sektor beserta segala konfektitas, penyebab, dan akibat masing-masing. Permasalahan tersebut antara lain mengenai permasalahan air, sampah, hutan, ekosistem pantai, perusahan. ${ }^{161}$

Adanya beberapa contoh kasus lingkungan tersebut menunjukkan bahwa dasar historis (sejarah) yang kuat untuk pengaturan lingkungan hidup telah diletakkan, yaitu melalui tindakan pemerintah guna melindungi masyarakat. ${ }^{162}$

\footnotetext{
${ }^{159}$ Mustamin, Hukum Lingkungan (Cet ;I;watampone, 2017), h.1

${ }^{160}$ Mustamin, Hukum Lingkungan, h. 1

${ }^{161}$ Mustamin, Hukum Lingkungan, h. 1

162 Gatot Soemartono, Hukum Lingkungan Indonesia, (Cet.I; Jakarta; Sinar Grafika, 1996), h.
} 
110 | Peran Dinas Lingkungan Hidup

Masalah lingkungan mulalui ramai dibicarakan sejak diselengarakan. Faktor terpenting dalam permasalahan lingkungan adalah besarnya populasi manusia (laju pertumbuhan penduduk). Dengan terus menipisya lapisan itu, sangat dikhawatirkan bila lapisan ini tidak ada atau menghilang sama sekali dari alam semesta ini. Tampa lapisan ozon sangat banyak akibat negative yang akan menimpa makhluk hidup di muka bumi, antara lain; penyakit-penyakit akan menyebar secara menjadi-jadi, cuaca tidak menentu, pemanasan global, bahkan hilangnya suatu daerah karena akan mencairnya yang ada dikutub utara dan selatan. Jakat raya hanya tinggal menunggu masa kehancuranya saja. Memang banyak cara yang harus dipilih untuk mengatasi masalah ini. Para ilmuan memberikan berbagai masukan untuk mengatasi masalah ini sesuai latar belakang keilmuanya. ${ }^{163}$

Berikut ini adalah contoh, penyebab atau dampak lingkungan;

a. Kekeringan : kekeringan adalah kekurangan air yang terjadi akibat sumber air tidak dapat menyediakan kebutuhan air bagi manusia dan makhluk hidup yang lainya.

Dampak : menyebabkan ganguan kesehatan, keterancaman pangan.

b. Banjir merupakan fonomena alam ketika sungai tidak dapat menampung limpahan air hujan karna proses influasi mengalami penurunan. Itu semua dapat terjadi karena hijauan penahanan air harian berkurang.

Dampak: ganguan kesehatan, penyakit kulit, aktifitas manusia terhambat, penurunan produktivitas pangan, dan lain-lain.

163 Mustamin, Hukum Lingkungan, h. 16 
c. Lonsor terkikisnya daratan oleh air karena penahanan air berkurang.

Dampaknya : terjadi kerusakan ladang, sawah, menggangu perekonomian dan kegiatan transportasi. ${ }^{164}$

Penyebab kerusakan lingkungan hidup secara umum biasa dikategorikan dalam dua faktor yaitu akibat peristiwa alam dan akibat ulah manusia. Banjir, abrasi, tanah lonsor, merupakan beberapa bencana alam. Meskipun jika ditelah lebih lanjut Banjir, abrasi, tanah lonsor biasa saja terjadi karena adanya campur tangan manusia juga. Pennyebab kerusakan lingkungan yang kedua adalah akibat ulah manusia. Kerusakan yang disebabkan oleh manusia ini justru lebih besar dibanding kerusakan akibat bencana alam. Ini mengigat kerusakan yang dilakukan biasa terjadi terus-menerus dan cenderung meningkat. Kerusakan ini umumnya disebabkan oleh aktivitas manusia yang tidak rama lingkungan. ${ }^{165}$

Umumnya ahli lingkungan membagikriteria lingkungan hidup dalam tiga golongan besar, yakni:

1. Lingkungan fisik: segala sesuatu di sekitar kita sebagai benda mati.

2. Lingkungan biologis: segala sesuatu di sekitar kita sebagai benda hidup.

3. Lingkungan sosial: adalah manusia yang hidup secara bermasyarakat.

Lingkungan alam merupakan prasyaratan pokok mengapa dan bagaimana pembagunan itu diselenggarakan. Bagi program pembagunan itu sendiri, apabila

\footnotetext{
${ }^{164}$ Mustamin, Hukum Lingkungan, h. 16

${ }^{165}$ Mustamin, Hukum Lingkungan, h. 17 
pelaksanaannya sesuai dengan program yang telah dijalankan, maka orientasi untuk menjaga lingkungan semesta pun akan bisa dilakukan. Sebaliknya, jika pembagunan dilakukan haya digunakan untuk mencapai tingginya tingkat pertumbuhan ekonomi semata, maka hal itu akan menimbulkan kerusakan lingkungan yang cukup serius. Salah satu produk dari kerusakan lingkungan itu adalah pencemaran, baik air, tanah, maupun udara. ${ }^{166}$

Ketentuan yang mengetahui upaya pencegahan pencemaran limbah Rumah Sakit di atur dalam Undang-Undang Nomor 32 Tahun 2009 Tentang Perlindungan dan Pengelolaan Lingkunagn Hidup, pada Pasal 13 ayat (1) bahwa "pengendalian pencemaran dan atau kerusakan lingkungan hidup dilaksanakan dalam rangka pelestarian fungsi lingkungan hidup". ${ }^{167}$

Dalam pandangan Islam, manusia ialah makhluk terbaik di antara semua ciptaan Tuhan dan berani memegang tanggung jawab mengelola bumi, maka semua yang ada di Bumi diserahkan untuk manusia. Oleh karena itu manusia di angkat menjadi khalifah di muka Bumi sebagai makhluk terbaik, manusia di berikan kelebihan di antaranya makhluk ciptaanya, yaitu kemuliaan, di berikan fasilitas di daratan dan lautan, mendapat rezki dari yang baik-baik, dan kelebihan yang sempurna atas makhluk lainnya.

Bumi dan semua isi yang berada didalamnya diciptakan Allah untuk manusia, segala manusia inginkan berupa apa saja yang ada dilangit dan dibumi.

\footnotetext{
${ }^{166}$ Rusmin tumanggor, Kholis ridho dan Nurochim, Ilmu sosial dan budaya dasar, (I,II,III,IV; Prenadamedia Group; Jakarta, 2010, 2012,2014,2015), h.185-186

167 Undang-undang Republik Indonesia Nomor 32 Tahun 2009 Tentang Perlindungan Dan Pengelolaan Lingkungan Hidup, h. 14
} 
Daratan dan lautan serta sungai-sungai, dan matarari, malam dan siang, tanama, dan buah-buahan, binatang,melata dan ternak. ${ }^{168}$

Berdasarkan hasil wawancara oleh ibu jumriani, SKM. M,Kes. seksi limbah bahan berbahaya dan beracun (B3) mengatakan bahwa semua Rumah Sakit sudah memiliki tempat penyimpanan sementara (TPS) limbah medis, dan pengelolaan instalasi pengolahan air limbah (IPAL) tidak dilakukan dengan sembarang di buang, karena ada tempat khusus yang dimentasinya didalamnya ada proses-proses yang dilakukan lalu dibuang ke lingkungan ${ }^{169}$. Tetapi ada masyarakat yang mengatakan bahwa rumah sakit itu mencemari masyarakat setempat. Berdasarakan hal tersebut Dinas Lingkungan Hidup Kabupaten Bone belum efektif, Karna masih adanya pencemaran yang terjadi. Adapun tujuan penelitian ini adalah untuk mengetahui apa faktor penghambat dan Upaya Yang Dilakukan Dinas Lingkungan Hidup Kabupaten Bone Dalam Mencegah Terjadinya Pencemaran Limbah Rumah Sakit.

\section{TINJAUAN PUSTAKA}

Tinjauan Pustaka berisi uraian hasil penelusuran peneliti tentang penelitian-penelitian yang telah ada dan dilakukan oleh orang lain akan tetapi memiliki tema yang sama. Meskipun demikian Tinjaun Pustaka ini dimaksudkan untuk memastikan bahwa pokok masalah yang akan diteliti berbeda dengan hasil penelitian terdahulu yang telah dilakukan oleh orang lain.

${ }^{168}$ Mustamin, Hukum Lingkungan, h. 93

${ }^{169}$ Wawancara ibu jumriani, jalan ord baru nomor 9,watampone, 23 oktober 2018 
Skripsi yang disusun oleh almukkaromi, mahasiswa program studi S1 ilmu pemerintahan FISIF universitas 2017 dengan judul pengawas badan lingkungan hidup terhadap limbah industry sagu dikabupaten kepulauan meranti sebagaimana hasil penelitiannya bahwa apa bila hasil limbah cair sagu melebihi standar baku mutu lingkungan hal ini di indikasikan sebagai sebuah pencemaran tidak wajar. Hal semacam ini dikarenakan kurangnya pengetahuan dan pemahaman pemilik industri tentang pentingnya pengelolaan limbah secara baik sehingga tidak mencemari lingkungan yang kemudian berdampak pada masyrakat. ${ }^{170}$

Perbedaan penelitian yang dilakukan oleh almukkaromi dengan peneliti yang dilakukan oleh peneliti yakni fokus utama penelitian skripsi ini mengarah pada limbah industry sagu sedangkan penelitian yang dilakukan oleh peneliti fokus pada limbah rumah sakit agar tidak terjadi pencemaran pada masyrakat.

Skripsi yang disusun oleh Muhammad arlen baihaki mahasiswa fakultas hukum universitas lampung Bandar lampung 2018 dengan judul peran dinas lingkungan hidup terhadap pengelolaan kualitas air dan pengendalian pencemaran air dikota metro sebagaiman dalam hasil penelitiannya, bahwa pembangunan di kota metro yang terus menerus memanfaatkan sumber daya alam guna meninggkatkan kesejahteraan dan mutu hidup masyrakat. Sementara itu, tersedianya sumber daya alam terbatas dan tidak merata, baik didalam jumlah maupun kualitas, sedangkan permintaan sumber daya alam tersebut semakin

${ }^{170}$ Skripsi yang disusun oleh almukkaromi, mahasiswa program studi S1 ilmu pemerintahan FISIF universitas 2017 dengan judul pengawas badan lingkungan hidup terhadap limbah industry sagu dikabipaten kepulauan meranti 
meningkat sebagai akibat meningkatnya pembangunanuntukmemenuhi kebutuhan masyrakat yang semakin meningkat yang beragam. ${ }^{171}$

Perbedaan penelitian yang dilakukan oleh Muhammad arlen baihaki dengan peneliti yang dilakukan oleh peneliti yakni fokus utama penelitian skripsi ini mengarah pada pengelolaan kualitas air dan pengendalian pencemaran air sedangkan penelitian yang dilakukan oleh peneliti fokus pada pencegahan terjadinya pencemaran limbah.

Jurnal yang disusun oleh Nadia Utami mahasiswa universitas hasanuddin gowa 2017 dengan judul analisis pengelolaan limbah medis padat pada klinik/praktek dokter di Kota Makassar sebagaimana dalam hasil penelitiannya, bahwa timbulan limbah medis fluktuatif setiap harinya pada masing-masing lokasi penelitian (klinik) adapun jenis serta komposisi limbah medis yang dihasilkan yaitu jenis infeksius $81 \%$, benda tajam 12\%, kimia 5\%, farmasi $2 \%$, radio aktif $0 \%$. Penanganan limbah medis mulai dari sumber sampai pengangkutan/ pengelolahan pada masing-masing lokasi penelitian atau klinik berpariasi. $^{172}$

Perbedaan penelitian yang dilakukan oleh Nadia utami dengan peneliti yang dilakukan oleh peneliti yakni fokus pada utama jurnal ini mengarah pada penanganan limbah medis mulai dari sumber sampai pengangkutan/ pengelolaan

${ }^{171}$ Skripsi yang disusun oleh Muhammad arlen baihaki mahasiswa fakultas hokum universitas lampung Bandar lampung 2018 dengan judul peran dinas lingkungan hidup terhadap pengelolaan kualitas air dan pengendalian pencemaran air dikota metro

172 Jurnal yang disusun oleh Nadia Utami mahasiswa universitas hasanuddin gowa 2017 dengan judul analisis pengelolaan limbah medis padat pada klinik/praktek dokter di Kota Makassar 
pada masing-masing lokasi penelitian atau klinik berpariasi sedangkan penelitian yang dilakukan oleh peneliti fokus pada pencemaran limbah rumah sakit.

Jurnal yang disusun oleh Trirahayu ningrum mahasiswa fakultas kesehatan masyarakat universitas jember 2013 dengan judul gambaran pengelolaan limbah cair di rumah sakit X Kabupaten Jenber sebagaimana dalam hasil penelitiannya, bahwa proses pengelolaan limbah cair di rumah sakit $\mathrm{X}$ jember sudah melakukan pengolohan limbah cairnya sendiri dengan menggunakan instalasi pengolahan air limbah (IPAL). hasil pemeriksaan kualitas limbah cairnya sudah memenuhi baku mutu lingkungan. ${ }^{173}$

Perbedaan penelitian yang dilakukan oleh Trirahayu dengan peneliti yang dilakukan oleh peneliti yakni fokus utama penelitian jurnal ini mengarah pada proses pengelohan limbah cair di rumah sakit $\mathrm{X}$ jember sudah memenuhi baku mutu lingkungan sendangkan penelitian yang dilakukan oleh peneliti fokus pada pencemaran limbah rumah sakit dimana instalasi pengolahan air limbahnya (IPAL) tidak memenuhi baku mutu air limbah karena masi adanya pencemaran yang terjadi di masyarakat.

Tesis yang disusun oleh Bestari alamsyah mahasiswa universitas diponegoro semarang 2007 dengan judul pengelolaan limbah di rumah sakit pupuk kaltim bontang untuk memenuhi baku mutu lingkungan sebagaimana dalam hasil penelitiannya, bahwa berdasarkan hasil wawancara dan hasil uji terhadap parameter fisik, kimia dan biologi, maka secara umum dapat

\footnotetext{
${ }^{173}$ Jurnal yang disusun oleh Trirahayu ningrum mahasiswa fakultas kesehatan masyarakat universitas jember 2013 dengan judul gambaran pengelolaan limbah cair di rumah sakit X Kabupaten Jenber
} 
disimpulkan bahwa pengelolaan limbah padat dan limbah gas dan limbah cair rumah sakit pupuk kaltim telah memenuhi baku mutu dan peraturan perundangundangan. ${ }^{174}$

Perbedaan penelitian yang dilakukan oleh Bestari alamsyah dengan penelitian yang dilakukan oleh peneliti yakni fokus utama penelitian tesis ini mengarah pada pengelolaan limbah padat dan limbah gas dan limbah cair rumah sakit pupuk kaltim telah memenuhi baku mutu dan peraturan perundangundangan sedangkan penelitian yang dilakukan oleh peneliti fokus pada pencegahan limbah pada rumah sakit.

Disertasi yang disusun oleh Peni pujiastuti mahasiswa unifersitas sebelas maret sukarta 2016 dengan judul kajian degradasi kualitas lingkungan perairan waduk sebagai dasar pengembangan model pengendalian pencemaran sebagaimana dalam hasi penelitiannya, bahawa sumber polotan dominan penyebab penurunan kualitas perairan waduk gajah mungkur (WGM) adalah kegiatan pertanian, domestik, industry tahu dan kantor jasa akuntansi (KJA).

Perbedaan penelitian yang dilakukan oleh Peni pujiastuti dengan peneliti yang dilakukan oleh peneliti yakni fokus utama penelitian disertasi ini mengarah pada dengan simulasi beban pencemaran waduk gajah mungkur dapat ditekan agar kualitas air waduk gajah mungkur memenuhi baku mutu kelas dua dengan menekan jumlah pakan, limbah industry tahu, domestic dan pertanian dan kantor

\footnotetext{
${ }^{174}$ Tesis yang disusun oleh Bestari alamsyah mahasiswa universitas diponegoro semarang 2007 dengan judul pengelolaan limbah di rumah sakit pupuk kaltim bontang untuk memenuhi baku mutu lingkungan
} 
Jasa Akutansi sedangkan penelitian yang dilakukan oleh peneliti fokus pada mencegah terjadinya pencemaran limbah rumah sakit disekitar masyarakat.

\section{METODE PENELITIAN}

Kata Metode berasal dari bahasa yunani methodos, terdiri dari dua kata yaitu meta berarti menuju, melalui, dan mengikuti, sedangkan hodos berarti jalan, cara dan arah. Jadi arti kata methodos adalah metode ilmiah yaitu cara melakukan sesuatu menurut aturan tertentu. ${ }^{175}$ Telah diketahui bahwa didalam penulisan suatu karya ilmiah harus didasarkan oleh metode, baik dari pengumpulan data maupun dari cara pengelolaannya. seperti dalam penyusunan skripsi ini dipergunakan metode sebagai berikut:

1. Jenis Penelitian

Adapun jenis penelitian yang digunakan dalam penelitian ini adalah penelitian lapangan (field reaserch), yaitu data utama diperoleh sendiri, dan peneliti secara langsung mengumpulkan informasi-informasi yang didapat dari orang yang diwawancarai atau responden terkait dengan Peran Dinas Lingkungan Hidup Kabupaten Bone dalam mencegah terjadinya pencemaran limbah rumah sakit berdasarkan Undang-Undang Nomor 32 tahun 2009 tentang perlindungan dan pengelolaan lingkungan hidup.

2. Pendekatan Penelitian

Pendekatan Penelitian merupakan proses kegiatan penyelidikan, pengumpulan, pengelolaan, analisis, dan penyajian data yang dilakukan secara

${ }^{175}$ Juliansyah Noor, Metodologi Penelitians,(Cet.IV: Jakarta; Kencana,2014), h. 22 
sistematis dan objek untuk memecahkan suatu persoalan sesuai objek yang diteliti. $^{176}$

Adapun pendekatan penelitian yang digunakan adalah:

Pendekatan normartif-empiris, penelitian hukum normatif yaitu penelitian yang mengacu kepada norma-norma hukum yang terdapat dalam peraturan perundang-perundangan dan putusan pengadilan serta norma-norma hukum yang ada dalam masyarakat. ${ }^{177}$ Penelitian hukum empiris yaitu pendekatan dengan melihat suatu kenyataan hukum di dalam masyarakat. ${ }^{178}$ karena mencari kesesuaian antara Undang-Undang dengan isu hukum yang terjadi yakni Dinas Lingkungan Hidup Kabupaten Bone dalam mencegah terjadinya pencemaran limbah rumah sakit berdasarkan undang-undang nomor 32 tahun 2009 tentang perlindungan dan pengelolaan lingkungan hidup.

\section{Lokasi penelitian}

Penelitian ini dilaksanakan di Kota Kabupaten Bone yakni di Dinas Lingkungan Hidup Kabupaten Bone yang berada di Jalan H. A. Mappayukki Kec. Tanete riattang barat, Kabupaten Bone. Adapun alasan penulis memilih lokasi penelitian ini, karena penulis merasa tertarik untuk mengetahui peran Dinas Lingkungan Hidup Kabupaten Bone dalam mencegah terjadinya pencemaran limbah rumah sakit berdasarkan Undang-Undang Nomor 32 tahun 2009 tentang perlindungan dan pengelolaan lingkungan hidup. Sebab dalam Kenyataannya

\footnotetext{
${ }^{176}$ Departement Pendidikan Nasional, Kamus Besar Bahasa Indonesia. h. 1163.

177 Zainuddin Ali, Metode Penelitian Hukum (Cet. V;jakarta;p Sinar Grafika, 2014), h.105

${ }^{178}$ Zainuddin Ali, Metode Penelitian Hukum, h. 105
} 
adalah dinas lingkungan hidup merupakan intansi yang mengawasi lingkungan hidup.

4. Data dan Sumber Data

a. Data

Data adalah segala keterangan (informasi) mengenai segala hal yang berkaitan dengan tujuan penelitian. Dengan demikian, tidak semua informasi atau keterangan merupakan data. Dan hanyalah sebagian saja dari informasi, yakni yang berkaitan dengan penelitian. ${ }^{179}$ Sesuai dengan fokus penelitian ini yaitu penelitian lapangan (field research) maka data-data yang akan dikumpulkan adalah data-data yang meliputi bahan data primer dan bahan data sekunder.

b. Sumber data

Sumber data dalam penelitian adalah subjek dari mana data diperoleh. ${ }^{180}$ Adapun sumber data yang digunakan dalam penelitian ini adalah sumber data primer dan sumber data sekunder :

1. Data primer adalah data yang diperoleh langsung dari sumbernya, baik melalui wawancara, observasi maupun laporan dalam bentuk dokumen tidak resmi yang kemudian diolah oleh peneliti. ${ }^{181}$ Data primer yang digunakan dalam penelitian ini yaitu data yang diperoleh secara langsung dari objek yang diteliti baik pribadi

${ }^{179}$ Tatang M. Amirin, Menyusun Rencana Penelitian (Cet. III; Jakarta: PT RajaGrafindo Persada, 1995), h. 130.

${ }^{180}$ Suharamis Arikunto, Penelitian Suatu Pendekatan Praktek (Cet. XII; Jakarta: Rineka Cipta, 2002), h. 107.

${ }^{181}$ Zainuddin Ali, Metode Penelitian Hukum, h. 106 
(responden) maupun dari suatu instansi yang mengolah data untuk keperluan penelitian, seperti dengan melakukan wawancara secara langsung dengan pihak-pihak yang berhubungan dengan penelitian yang dilakukan.Adapun data primer yang dimaksud oleh peneliti disini yaitu data yang diperoleh langsung dari Dinas Lingkungan Hidup Kabupaten Bone, data dari masyarakat yang berada disekitar rumah sakit.

2. Data sekunder adalah data yang diperoleh dari dokumen-dokumen resmi, buku-buku yang berhubungan dengan objek penelitian, hasil penelitian dalam bentuk laporan, skripsi, tesis, disertasi, dan peraturan perundang-undangan. Data sekunder tersebut, dibagi menjadi tiga, yaitu:

4) Bahan hukum primer yang mengikat terdiri dari peraturan perundang-undangan yang terikat dengan objek penelitian. Bahan hukum primer dalam penelitian ini adalah UndangUndang Nomor 32 Tahun 2009 tentang perlindungan dan pengelolaan lingkungan hidup.

5) Bahan hukum sekunder yang terdiri dari buku-buku dan tulisan-tulisan ilmiah hukum yang terkait dengan peran Dinas Lingkungan Hidup Kabupaten Bone dalam mencegah terjadinya pencemaran limbah rumah sakit

6) Bahan hukum tersier yaitu petunjuk atau penjelasan mengenai bahan hukum primer atau bahan hukum 
sekunder yang berasal dari kamus, ensiklopedia, majalah, surat kabar, dan sebagainya. ${ }^{182}$

\section{Instrument Penelitian}

Instrumen penelitian atau alat pengumpulan data bertujuan untuk menentukan kualitas penelitian, karena itu, alat pengumpulan data harus mendapat penggarapan yang cermat. Lazimnya dalam penelitian dikenal tiga jenis alat pengumpulan data studi dokumen atau bahan pustaka, pengamatan atau observasi, dan wawancara atau interview ${ }^{183}$. Instrumen yang digunakan dalam penelitian ini yakni, handphone untuk memudahkan merekam suara responden serta daftar pertanyaan dan alat tulis sebagai pedoman wawancara dan observasi.

6. Tehnik pengumpulan data

Dalam mengumpulkan data peneliti menempuh hal-hal sebagai berikut:

c. Studi Dokumen atau Bahan Pustaka

Studi dokumen merupakan langkah awal dari setiap penelitian hukum (baik normatif maupun sosiologis), studi dokumen bagi penelitian hukum meliputi studi bahan-bahan hukum yang terdiri dari bahan hukum primer, bahan hukum sekunder, dan bahan hukum tersier. Setiap bahan hukum ini harus diperiksa ulang validitas dan kredibilitasnya. Sebab, hal ini sangat menentukan hasil suatu pnelitian. ${ }^{184}$

\footnotetext{
${ }^{182}$ Zainuddin Ali, Metode Penelitian Hukum, h. 106

${ }^{183}$ Amiruddin dan Zainal Asikin, Pengantar Metode Penelitian Hukum, (Cet.II; Jakarta:Raja Grafindo Persada, 2004), h. 65-67.

${ }^{184}$ Amiruddin dan Zainal Asikin, Pengantar Metode Penelitian Hukum, (Cet.II; Jakarta:Raja Grafindo Persada, 2004), h. 68
} 
d. Interview (wawancara), yaitu situasi peran antara antar pribadi bertatap muka, ketika seseorang yakni pewawancara mengajukan pertanyaan-pertanyaan yang dirancang untuk memperoleh jawabanjawaban yang relevan dengan masalah penelitian kepada seseorang responden. ${ }^{185}$ Wawancara dapat dilakukan baik melalui tatap muka (face to face) maupun pesawat telepon. Melalui kedua cara ini, akan selalu terjadi kontak pribadi. Oleh karena itu, pewawancara perlu memahami situasi dan kondisi sehingga dapat memilih waktu yang tepat kapan dan dimana wawancara harus dilakukan. ${ }^{\mathbf{1 8 6}}$ Wawancara dilakukan dengan seksi limbah B3 yakni Jumriani, SKM., M, Kes, seksi pemantauan lingkungan yakni Nufyanti Nufri, SKM dan seksi pencemaran lingkungan Ridwan SE.

\section{Tehnik Analisis Data}

Adapun teknik analisis data yang digunakan dalam penelitian ini adalah analisis data secara kualitatif terhadap data primer dan data sekunder atau penelitian yang bermula dari pengamatan. Analisis data dalam penelitian kualitatif meliputi tiga tahap, tahap pertama adalah tahap kodifikasi data merupakan tahap pekodingan terhadap data, yang dimaksud dengan pekodingan data adalah peneliti memberikan nama atau penamaan terhadap hasil penelitian. ${ }^{\mathbf{1 8 7}}$ Tahap kedua adalah tahap penyajian data merupakan sebuah tahap lanjutan analisis di mana peneliti menyajikan temuan penelitian berupa kategori

\footnotetext{
${ }^{185}$ Amiruddin dan Zainal Azikin, Pengantar Metode Penelitian Hukum, h. 82.

${ }^{186}$ Rukaesih A. Maolani dan Ucu Cahyana, Metodologi Penelitian Pendidikan. h. 153

${ }^{187}$ Afrizal, Metode Penelitian Kualitatif (Cet. I; Jakarta: PT RajaGrafindo Persada, 2014) h. 178.
} 
atau pengelompokan dengan menggunakan matriks dan diagram untuk menyajikan hasil penelitian. ${ }^{\mathbf{1 8 8}}$ Tahap ketiga adalah tahap penarikan kesimpulan atau verifikasi merupakan suatu tahap lanjutan di mana pada tahap ini peneliti menarik kesimpulan dari temuan data, ini adalah interpretasi peneliti atas temuan dari suatu wawancara atau sebuah dokumen. ${ }^{189}$

\section{HASIL PENELITIAN DAN PEMBAHASAN}

\section{Apa Faktor penghambat Dinas Lingkungan Hidup Kabupaten Bone dalam mencegah terjadinya pencemaran limbah rumah sakit}

Manusia didalam pergaulan hidup, pada dasrnya mempunyai pandanganpandangan tertentu mengenai apa yang baik dan apa yang buruk. Pandanganpandangan tersebut senantiasa terwujud di dalam pasangan-pasangan tertentu, misalnya, ada pasangann nilai ketertiban dengan nilai kepentingan pribadi, pasangan nilai kelestarian dengan nilai inovatisme, dan seterusnya. Di dalam penegakan hukum, pasangan nila-nilai tersebut perlu diserasikasan; umpamanya, perlu penyerasian antara nilai ketertiban bertitik tolak pada keterikatan, sedangkan nilai ketentraman titik tolaknya adalah kebebasan. Di dalam kehidupannya, maka manusia memerlukan keterikatan maupun kebebasan di dalam wujud yang serasi. ${ }^{190}$ Faktor-faktor tersebut mempunyai arti yang netral, sehingga dampak positif atau negatifnya terletak pada isi faktor-faktor tersebut. Faktor-faktor tersebut, adalah sebagai berikut:

\footnotetext{
${ }^{188}$ Afrizal, Metode Penelitian Kualitatif, h. 179

${ }^{189}$ Afrizal, Metode Penelitian Kualitatif, h. 180

${ }^{190}$ Soerjono soekanto, faktor-faktor yang mempengaruhi penegakan hukum, (Cet ke XI dan
} XII; Jakarta: PT Raja Grafindo Persada, 2013), h. 5-6 
1. Faktor hukumnya sendiri, yang di dalam tulisan ini akan dibatasi pada undang-undang saja.

2. Faktor penegakan hukum, yakni pihak-pihak yang membentuk maupun penerapan hukum.

3. Faktor sarana atau fasilitas yang mendukung penegakan hukum.

4. Faktor masyarakat, yakni lingkungan di mana hukum tersebut berlaku atau diterapkan.

5. Faktor kebudayaan, yakni sebagai hasil karya, cipta, dan rasa yang didasarkan pada karsa manusia didalam pergaulan hidup.

Kelima faktor tersebut saling berkaitan dengan eratnya, oleh karena merupakan esensi dari penegakan hukum, juga merupakan tolak ukur daripada efektifitas penegakan hukum. Dengan demikian, maka kelima faktor tersebut akan dibahas di sini, dengan cara mengetengahkan contoh-contoh yang diambil dari kehidupan masyarakat Indonesia. ${ }^{191}$

Tanpa adanya sarana atau fasilitas tertentu, maka tidak mungkin penegakan hukum akan berlangsung dengan lancar. Sarana atau fasilitas tersebut, antara lain, mencakup tenaga manusia yang berpendidikan dan terampil, organisasi yang baik, peralatan yang memadai, keuangan yang cukup, dan seterusnya. Kalau hal-hal itu tidak dipenuhi, maka mustahil penegakan hukum akan mencapai tujuannya. Agar masalah tersebut dapat dipahami dengan mudah, akan disajikan suatu contoh menegenai proses peradilan. ${ }^{192}$

\footnotetext{
${ }^{191}$ Soerjono soekanto, faktor-faktor yang mempengaruhi penegakan hukum, (Cet ke XI dan XII; Jakarta: PT Raja Grafindo Persada, 2013), h. 8-9

${ }^{192}$ Soerjono soekanto, faktor-faktor yang mempengaruhi penegakan hukum, (Cet ke XI dan XII; Jakarta: PT Raja Grafindo Persada, 2013), h. 37
} 
Suatu masalah lain yang erat hubunganya dengan penyelesaian perkara dan sarana atau fasilitasnya, adalah soal efektifitas dari sanksi negative yang diancamkan terhadap peristiwa-peristiwa pidana tertentu. Tujuan sanksi-sanksi tersebut dapat mempunyai efek yang menakutkan terhadap pelanggaranpelanggaran potensial, maupun yang perna dijatuhi hukuman karena perna melanggar (agar tidak mengulanginya lagi). Dengan demikian diharapkan, bahwa kejahatan akan berkurang secara semaksimal mungkin. ${ }^{193}$

Penegakan hukum berasal dari masyarakat, dan bertujuan untuk mencapai kedamaian di dalam masyrakat. Oleh karena itu, dipandang dari sudut tertentu, maka masyrakat dapat mempengaruhi penegakan hukum tersebut. Di dalam bagian ini, diketengahkan secara garis besar perihal pendapat-pendapat masyarakat mengenai, yang sangat mempengaruhi kepatuhan hukumnya. Kiranya jelas, bahwa hal ini pasti ada kaitannya faktor-faktor terdahulu, yaitu undangundang, penegak hukum, dan sarana atau fasilitas. Pertama-tamaada perbagai pengertian atau arti yang diberikan pada hukum, yang variasinya adalah:

1. Hukum diartikan sebagai ilmu pengetahuan,

2. Hukum diartikan sebagai disiplin, yakni sistem ajaran tentang kenyataanm,

3. Hukum diartikan sebagai norma atau kaidah, yakni patokan perilaku pantas yang diharapkan,

4. Hukum diartikan sebagai tata hukum (yakni hukum positif tertulis),

5. Hukum diartikan sebagai petugas ataupun pejabat,

\footnotetext{
${ }^{193}$ Soerjono soekanto, faktor-faktor yang mempengaruhi penegakan hukum, (Cet ke XI dan XII; Jakarta: PT Raja Grafindo Persada, 2013), h. 41-42
} 
6. Hukum diartikan sebagai keputusan pejabat atau penguasa,

7. Hukum diartikan sebagai proses pemerintahan,

8. Hukum diartikan sebagai perilaku teratur dan unik,

9. Hukum diartikan sebagai jalinan nilai,

10. Hukum diartikan sebagai seni.

Dari sekian banyaknya pengertian yang diberikan pada hukum, terdapat kecenderungan yang besar pada masyrakat, untuk mengartikan hukum dan bahkan mengidentifikasikannya dengan petugas (dalam hal ini penegakan hukum sebagai pribadi). Salah satu akibatnya adalah, bahwa baik buruknya hukum senantiasa dikaitkan dengan pola prilaku penegak hukum tersebut, yang menurut pendapatnya merupakan pencerminan dari hukum sebagai struktur proses. Untik jelasnya, akan dikemukakan suatu contoh yang diambil dari suatu unsure kalangan penegak hukum, yakni polisi yang dianggap sebagai hukum oleh masyrakat luas (disamping unsure-unsur lainnya, seperti misalnya, hakim, jaksa, dan seterusnya). ${ }^{194}$

Berdasarkan dari wawancara Ibu Nufayanti Nufri, SKM seksi pemantauan lingkungan di Kantor Dinas Lingkungan Hidup Kabupaten Bone, Faktor penghambat dalam mencegah terjadinya pencemaran lingkungan hidup mengatakan bahwa :

1. Instalasi pengolahan air limbah (IPAL) yang tidak berfungsi dengan baik.

\footnotetext{
${ }^{194}$ Soerjono soekanto, faktor-faktor yang mempengaruhi penegakan hukum, (Cet ke XI dan XII; Jakarta: PT Raja Grafindo Persada, 2013), h. 45-47
} 
2. Kurangnya pengawasan dari dinas lingkungan hidup

3. Kapasitas limbahnya sudah melebihi dari pada kapasitas pengolahannya

4. Kurangnya kompratif dari pihak rumah sakit. ${ }^{195}$

Pengendalian pencemaran air dilakukan melalui langak-langka berikut: penetapan daya tamping beban pencemaran pada setiap sumber air, inventarisasi dan identifikasi sumber pencemaran air, penetapan pensyaratan air limbah untuk aplikasi ketanah, penetapan pensyaratan pembuangan air limbah ke air atau sumber-sumber air, pemberlakuan isin pemanfaatan air limbah ketanah dan isin pembuangan air limbah keair atau sumber ke air, dan pemantauan kualitas air pada sumber air.

Adapun hasil wawancara peneliti dengan masyrakat yang berada disekitar rumah sakit mengatakan bahwa :

Tidak adanya pencemaran yang dialami masyarakat yang tepatnya berada di sebelah kanan rumah sakit dan dia mengarahkan peneliti ke sebelah kiri rumah sakit karena disitu terdapat pencemaran jadi untuk lebih jelasnya peneliti diarahkan untuk mewawancarai masyarakat yang berada di sebelah kiri rumah sakit. ${ }^{196}$

Adapun hasil wawancara peneliti dengan masyarakat yang berada disekitar rumah sakit mengatakan bahwa :

${ }^{195}$ Nufyanti nufri, SKM Seksi Pemantauan Lingkungan, WawancaraOleh Penulis di Dinas Lingkungan Hidup Kabupaten Bone, 01 agustus 2019

${ }^{196}$ Ibu Rahmatia, Masyarakat, wawancara, oleh penulis di sekitar rumah sakit, 03 selasa 2019 
Awal berdirinya rumah sakit yaitu mengeluarkan bauh yang tidak sedap hinga sampai saat ini masih ada bau yang sering keluar dan kadang ada dan kadang juga tidak ada. ${ }^{197}$

Berdasarkan hasil wawancara dari peneliti dapat simpulkan bahawa pernyataan dari masyarakat yang berada di sebelah kanan rumah sakit tidak mengalami pencemaran limbah rumah sakit tetapi masyarakat yang berada di sebelah kiri rumah sakit mengalami pencemaran limbah rumah sakit. Berdasarkan pernyataan masyarakat di atas bahwa rumah sakit tidak mengikuti aturan-aturan dari Dinas Lingkungan Hidup Kabupaten Bone.

Berdasarkan hasil wawancara peneliti ke ibu Jumriani, SKM, M.Kes seksi Limbah B3 di Kantor Dinas Lingkungan Hidup Kabupaten Bone mengatakan bahwah :

Rumah sakit Kabupaten Bone sudah memiliki tempat penyimpanan sementara (TPS) limbah bahan berbahaya dan beracun (B3) dan mereka sudah bekerja sama dengan pihak transporter dan mitra hijau, dalam hal ini mitra hijau mengangkut limbah medis dan pihak III sebagai pengolah limbah bahan berbahaya dan beracun (B3). ${ }^{198}$

Adapun hasil wawancara peneliti dengan masyarakat lain mengatakan bahwa :

Awal berdirinya rumah sakit yaitu mengeluarkan bau yang sedap hingga sampai saat ini masi mengeluarkan bau, kadang ada dan kadang tidak ada, jika hujan siang dan malam maka air limbah rumah sakit keluar dari

\footnotetext{
${ }^{197}$ Nirwana, Masyarakat, Wawancara, Oleh Penulis di sekitar Rumah Sakit, 23 Juli 2019

198 Jumriani, SKM, M.Kes, seksi Limbah B3, wawancara oleh penulis di Dinas Lingkungan
} Hidup Kab. Bone, 22 juli 2019 
saluran pipa dan perairannya lari ke sawah sehingga mengeluarkan bau yang tidak sedap dan menganggu kenyamanan masyrakat. ${ }^{199}$

Berdasarkan hasil wawancara dari peneliti dapat dibedahkan bahwa pernyataan dari Dinas Lingkungan Hidup Kabupaten Bone sangat berbeda dengan hasi pernyataan dari masyarakat yang berada disekitar rumah sakit dimana Dinas lingkungan hidup Kabupaten Bone mengatakan bahwa semua penyimpanan limbah B3 sudah lancar akan tetapi menurut masyarakat rumah sakit masi mengeluarkan bau yang tidak sedap dan bahkan mengeluarkan air limbahnya. Jadi peneliti dapat simpulkan bahwa Dinas Lingkungan Hidup Kabupaten Bone belum efektif karena masi ada rumah sakit yang mencemari masyarakat disekitar.

Berdasarkan hasil wawancara Bapak Ridwan, SE seksi pencemaran lingkungan di Kantor Dinas Lingkungan Hidup Kabupaten Bone mengatakan bahwa :

Apabila rumah sakit melakukan pencemaran di masyrakat maka Dinas Lingkungan Hidup Kabupten Bone melakukan peringatan atau himbauan dan di tegur secara lisan. ${ }^{200}$

\section{Apa UpayaYang DilakukanDinas Lingkungan Hidup Kabupaten Bone Dalam}

\section{Mencegah Terjadinya Pencemaran Limbah Rumah Sakit}

Setiap orang berkewajiban memelihara kelestarian lingkungan hidup mencegah dan menanggulangi pencemaran serta perusakan lingkungan hidup. Karena itu, setiap kegiatan yang berakibat pada kerusakan lingkungan, seperti

\footnotetext{
${ }^{199}$ Suami pg anti, massyarakat, wawancara, oleh penulis di sekitar Rumah Sakit, 30 juli 2019

${ }^{200}$ Ridwan, SE, Seksi Pencemaran Lingkungan, wawancara, oleh penulis di Kantor Dinas Lingkungan Hidu Kabupaten Bone, 04 september 2019
} 
pencemaran lingkungan dan pembuangan zat berbahaya (B3) melebihi ambang batas baku mutu bisa dikategorikan sebagai perbuatan yang bertentangan dengan hukum, sehingga dapat dikenai sanksi, baik sanksi administrasi, perdata, maupun pidana. $^{201}$

Berdasarkan dari wawancara Ibu Nufyanti nufri, SKM Seksi Pemantauan Lingkungan, di Kantor Dinas Lingkungan Hidup Kabupaten Bone mengatakan bahwa :

Dalam upaya mencegah terjadinya pencemaran limbah yaitu :

1. Pemantauan

Bahan pemantauan yaitu dengan mengabil berita acara dan pengambilan sampel, catatan lapangan untuk sampel kemudian Dinas Lingkungan Hidup Kabupaten Bone datang langsung melihat kinerja rumah sakit dalam proses pemeriksaan parlementernya dan limbahnya setelah itu Dinas Lingkungan Hidup Kabupaten Bone mengambil sampelnya dan di bawah ke laboraterium Dinas Lingkungan Hidup untuk diuji limbahnya apakah sudah memenuhi baku mutu air limbanya atau belum.

2. penyeluhan kesehatan/promosi

3. pengawasan

pengawasan yang dilakukan Dinas Lingkungan Hidup Kabupaten Bone kepada setiap rumah sakit agar tidak terjadi pencemaran

${ }^{201}$ Mustamin, Hukum Lingkungan, h. 49-50

Jurnal Al-Dustur; VOLUME 2 NO 2, DESEMBER 2019 
dimasyarakatmaka Dinas Lingkungan Hidup memberikan arahan maupun saran ke pada pihak Rumah Sakit. ${ }^{202}$

Dalam masyarakat yang mengalami pencemaran atau terganggu dengan adanya pencemaran limbah rumah sakit maka masyarakat bisa melakukan pengaduan kepada Dinas Lingkungan Hidup Kabupaten Bone.

Berdasarkan hasi wawancara Ibu A. Marliya H, ST, M.Si seksi pengaduan dan penyelesaian sengketa lingkungan di Kantor Dinas Lingkungan Hidup Kabupaten Bone mengatakan bahwa :

Ada format pengisian pengaduan bagi masyarakat yang mengalami pencemaran, tetapi terkadang masyarakat tidak tahu hal melakukan format pengisian ini tapi dia melakukan surat pengaduan ke Dinas Lingkungan Hidup Kabupaten Bone. Ada dua langka yang bisa dilakukan dalam pengaduan :

1. datang langsung ke Dinas Lingkungan Hidup Kabupaten Bone, langsung kita kasi format tentang pengaduan.

2. Bisa juga melainkan surat melalui Dinas Lingkungan Hidup atas komplen dari masyarakat.

Karena selama ini rata-rata itu masyarakat kekantor Lurah duluh dalam artian pemerintahan terkecil duluh dan memberikan suratnya. Kantor Lurahnya menyurat ke Kantor Dinas Lingkungan Hidup Kabupaten Bone bahwa ada pencemaran diwilayahnya setelah diterimah suratnya nanti diposisikan kita untuk turun langsung kelapangan/ previkasi

\footnotetext{
${ }^{202}$ Nufyanti nufri, SKM, Seksi Pemantauan Lingkungan, WawancaraOleh Penulis di Dinas Lingkungan Hidup Kabupaten Bone, 01 Agustus 2019
} 
melakukan konsep seperti apa dampaknya ini pengaduan dari masyarakat. ${ }^{203}$

Adapun peneliti yang bisa di pahami dari pernyataan Ibu A. Marliya H, ST, M.Si bahwa apabila ada pengaduan dari masyarakat maka pihak Dinas Lingkungan Hidup Kabupaten Bone turun langsung melihat situasi rumah sakit, apakah benar pengaduan dari masyrakat tentang pencemaran limbah rumah sakit dan jika benar maka Dinas Lingkungan Hidup Kabupaten Bone memberikan peringatan dan arahan kepada pihak rumah sakit agar lebih memperhatikan instalasi pengolahan air limbah (IPAL) dan mengontrol dengan baik agar tidak terjadi pencemran di masyarakat.

Berdasarkan hasil wawancara ibu Jumriani, SKM, M.Kes seksi limbah Bahan berbahaya dan beracun (B3) di Kantor Dinas Lingkungan Hidup Kabupaten Bone, dalam proses pengelolaan limbah B3 yaitu :

Prosesnya yaitu dilakukan instalasi pengolahan air limbah (IPAL) misalnya harus dilakukan pengujian terlebih dahulu jika tidak memenuhi syarat baku mutu air limbah maka tidak dikeluarkan ijin diapun harus membuat kajian permasalahan disekitarnya mulai dari permasalahn kesehatannya, permesalahan pencemaran terhadap transporter dengan masyrakat disekitar. Sistem pengelolaan instalasi pengelolaan air limbah (IPAL) tidak dilakukan dengan sembarang dibuang ada tempat khusus yang dimentasinya, didalamnya ada prosesproses yang dilakukan lalu dibuang dilingkungan, sebelum dibuang

203 A. marliya H, ST, M.Si, Seksi pengaduan dan penyelesaian sengketa lingkungan, wawancara oleh penulis di Kantor Dinas Lingkungan Hidup Kabupaten Bone, 03 agustus 2019 
kelingkungan itu diuji duluh apakah sudah memenuhi syarat baku mutu air limbah yang dipersyaratkan dilingkungan. ${ }^{204}$

\section{PENUTUP}

\section{Kesimpulan}

1. Dari beberapa komponen pengelolaan limbah rumah sakit yang ada di Dinas lingkungan hidup Kabupate Bone memiliki faktor penghambat. Beberapa faktor penghambat adalah faktor yang berasal dari instalasi pengolahan air limbah (IPAL) yang tidak berfungsi dengan baik, kurangnya pengawasan dari Dinas lingkunga hidup, kapasitas limbahnya sudah melebihi dari pada kapasitas pengolahannya, kurangnya kompratif dari pihak rumah sakit

2. Upaya Dinas lingkungan hidup Kabupaten Bone terhadap pencemaran limbah rumah sakit adalah Dinas lingkungan hidup dating langsung melihat kinerja rumah sakit dalam proses pemeriksaan parlamenternya dan limbahnya (pemantauan), melakukan penyuluhan kesehatan/ promosi dan pengawasan yang dilakukan Dinas lingkungan hidup kepada setiap rumah sakit agar tidak terjadi pencemaran di masyrakat.

\section{DAFTAR REFERENSI}

Afrizal, Metode Penelitian KualitatifCet. I; Jakarta: PT RajaGrafindo Persada, 2014

Ali, Zainuddin. Metode Penelitian Hukum Cet. V; jakarta;p Sinar Grafika, 2014

${ }^{204}$ Jumriani, SKM, M.Kes, Seksi Limbah Bahan Berbahaya dan Beracun (B3), WawancaraOleh Penulis di Kantor Dinas Lingkungan Hidup Kabupaten Bone, 22 Juli 2019 
Amirin M Tatang, Menyusun Rencana Penelitian Cet. III; Jakarta: PT RajaGrafindo Persada, 1995

Amiruddin dan Zainal Asikin.Pengantar Metode Penelitian Hukum.Cet. I; Jakarta: PT. Grafindo Persada.

Arikunto Suharamis, Penelitian Suatu Pendekatan Praktek Cet. XII; Jakarta: Rineka Cipta, 2002

Departement Pendidikan Nasional, Kamus Besar Bahasa Indonesia.

Erwin Muhammad,Hukum Lingkungan Dalam Sistem Kebijaksanaan Pembangunan Lingkungan Hidup, Cet. I dan II;jl.mangger girang no. 98, bandung,2009

Faishal Achmad, Hukum lingkungan pengaturan limbah dan paradigma industry hijau, Cet I; Yogyakarta: PT buku seru, 2016

Jurnal yang disusun oleh Nadia Utami mahasiswa universitas hasanuddin gowa 2017 dengan judul analisis pengelolaan limbah medis padat pada klinik/praktek dokter di Kota Makassar

Jurnal yang disusun oleh Trirahayu ningrum mahasiswa fakultas kesehatan masyarakat universitas jember 2013 dengan judul gambaran pengelolaan limbah cair di rumah sakit X Kabupaten Jenber

Maolani A. Rukaesih dan Ucu Cahyana, Metodologi Penelitian Pendidikan, Cet. I; Jakarta: PT Raja Grafindo Persada, 2015

Mustamin, Hukum Lingkungan cet.I;watampone, 2017

Noor Juliansyah, Metodologi Penelitian,Cet.IV: Jakarta; Kencana,2014

Rahmadi Takdir, Hukum Lingkungan Indonesia, Cet ke V; Jakarta: PT Raja Grafindo Persada, 2015 
satria Ase defenisi peran dan pengelompokan menurut para ahli http://www.materibelajar.id/2016/01/defenisi-peran-dan-pengelompokanperan.htmI?m=1\#

Skripsi yang disusun oleh almukkaromi, mahasiswa program studi S1 ilmu pemerintahan FISIF universitas 2017 dengan judul pengawas badan lingkungan hidup terhadap limbah industry sagu dikabipaten kepulauan meranti

Skripsi yang disusun oleh Muhammad arlen baihaki mahasiswa fakultas hukum universitas lampung Bandar lampung 2018 dengan judul peran dinas lingkungan hidup terhadap pengelolaan kualitas air dan pengendalian pencemaran air dikota metro

SoekantoSoerjono, faktor-faktor yang mempengaruhi penegakan hukum, Cet ke XII; Jakarta: PT Raja Grafindo Persada, 2013

Soemartono Gatot, Hukum lingkungan Indonesia, cet.I; Sinar Grafika; Jakarta, 1996 soemartono P. Gatot, hukum lingkungan Indonesia, TC; sinar Grafika; Jakarta, 13220 Tesis yang disusun oleh Bestari alamsyah mahasiswa universitas diponegoro semarang 2007 dengan judul pengelolaan limbah di rumah sakit pupuk kaltim bontang untuk memenuhi baku mutu lingkungan

Tumanggor Rusman, Kholis ridho dan Nurochim, Ilmu sosial dan budaya dasar, I,II,III,IV; Prenadamedia Group; Jakarta, 2010, 2012,2014,2015

Undang-Undang Republik Indonesia Nomor 32 Tahun 2009 Tentang Perlindungan Dan Pengelolaan Lingkungan Hidup 